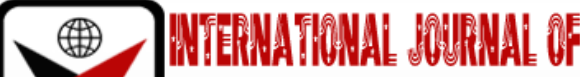

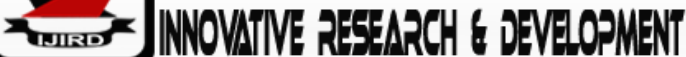

ISSN 2278 - 0211 (Online)

\section{The Impact of Positive and Negative Cultural Expressions of Masculinities on Educational Processes}

\begin{tabular}{|c|}
\hline Rachel Wairimu Njuguna \\
Teacher, Department of Sociology, Gender and Development Studies, \\
Kenyatta University, Kenya \\
Pacificah Okemwa \\
Lecturer, Department of Sociology, Gender and Development Studies, \\
Kenyatta University, Kenya \\
Leah Wanjama \\
Senior Lecturer, Department of Sociology, Gender and Development Studies, \\
Kenyatta University, Kenya \\
\hline
\end{tabular}

\begin{abstract}
:
The larger study from which this article is drawn was on cultural expressions of masculinities and its effects on the educational processes among the Samburu and Turkana communities in Kenya. The comparative case study was conducted at Maralal Mixed Day Secondary School in Samburu Central constituency in Ikuruto Division of Samburu County. The respondents of the study were 12 Turkana boys, 30 Samburu boys and 36 girls, giving a total of 78 student respondents; 3 education officials and 11 teachers (both male and female and inclusive of the principal and deputy principal). The initiation of Turkana and Samburu boys led to cultural masculinity expressions such as authority of male over females, adornment in traditional attire and involvement in male-related activities like raiding for cattle among others. The expected ensuing behaviour would be the show of bravery, aggressiveness and diligence in dealing with many issues facing them in the classroom setting. The study findings indicated that these cultural expressions of masculinities among the Turkana and Samburu boys have both positive and negative effects on their education processes. The positive effects included better ways of dealing with life issues, intercommunity unity and better prospects of employment. On the other hand, the initiated boys found it difficult to be taught by female teachers or perform well in subjects that were perceived as girl-oriented such as Languages. They sometimes also perceived education as undermining to their cultural values.
\end{abstract}

Keywords: Cultural expressions of masculinity, Education, processes, samburu and Turkana boys

\section{Introduction}

The school as an integral part of society can be said to be a place of the differentiation of masculinities between different men (Connell, 2010). Further, the effects of masculinities can be manifested, notably in relation to authority patterns, the academic curriculum, and effects of failure; coupled with dimensions of knowledge such as dealing with persons of the opposite gender. Education has been greatly linked with gender issues, especially masculinities and its implications on the academic performance of boys. Heyder and Kessels (2013) argue that issues of masculinities among boys may either manifest themselves as positive attributes or a crisis that many boys struggle to live up to. As DiPrete and Buchmann (2013) note, there is a clear gender divide in education as far as boys' needs in schools are concerned. Going by the fact that boys are exposed to different societal players who influence their self-perception, it is argued that expressions of masculinities continually change and that their impact on different sectors such as education cannot be ignored (Coffey \& James, 2016; Haywood \& Mac an Ghaill, 2013). Of essence, is to question if academic performance, violence, stoicism, aggressiveness among other attributes is linked to traditional masculine culture among boys in the school setting.

Globally, the connections between cultural expressions of masculinities and education remain visible through scholars and writers; with findings that pointing to some positive influences on boy school performance. Leaper, Farkas and Brown (2012) as well as Martino (2008) observe that boys' gender typicality will not adversely impact male-typed subjects that could strengthen their gender identity, such as Maths or Science. They however, are harmful to cross-sex typed subjects, such as English, that could seemingly weaken their masculine identity and/or status. Paradoxically, these trends may also cause difficulties for boys in schools since masculinity is linked with success and dominance. Hargreaves, Homer and Swinnerton (2008) conducted a study in England on the performance of Mathematics among boys and girls. The findings showed that attitudinal differences indicated a stereotypical view of Mathematics as a subject that is purely a boys' subject. Boys conveyed cultural expressions of their masculinities of confidence that made them to perform better in the subject than girls. Only a few 'gifted girls' managed to attain the boys' level of performance in the subject. In Kenya, 
cultural expressions of masculinities have helped many boys succeed in STEM (Science, Technology, Engineering and Mathematics) subjects due to the brevity and toughness they present in class. Kitetu (2008) writes that since these boys want to prove a point, they tend to struggle and successfully accomplish good grades in subjects such as Computer Studies.

In contrast, cultural expressions of masculinities have been observed to have adverse effects on boys' educational processes. According to Abbott (2013) very many young boys in the UK visualize education as not being macho enough. The author is, therefore, wary of the fact that the British rites of passages for the boys have slowly deviated from hard work, appreciation of the community to hyper-masculinity that emphasizes lack of respect for women's autonomy, heartlessness and even crude individualism (Abbott, 2013; Connell \&Messerschmidt, 2005). In reference to AfricanCaribbean boys, especially those from poor families, Richardson (2011), reports that black schoolboys perform poorly in schools as exemplary performance undermines their masculinities. Christine and Becky (2003) explain the concept of 'laddishness' in Indian classrooms. From the construction of masculinities in the Indian communities, boys learn to be competitive, macho and laddish as some of the expressions of their masculinity constructions. However, instead of using these manifestations positively in their participation in educational processes, Indian boys gradually alienate themselves from the school setting as they focus on positioning themselves as 'hard' and 'cool'. The boys also struggle to distance themselves from being termed as intelligent and geniuses; aspects that are construed as weak and lacking of vigour which is uncharacteristic of men (Epstein et al., 1998; Francis, 2000; Warrington \& Younger, 2000).

In Botswana and Lesotho for example, Jha and Kelleher (2006) indicate that boys are socialized to conform to a masculine gender identity that does not match with the demands of education. For the Keiyo boys Chang'ach (2013) notes that once these boys have undergone traditional circumcision, their behaviour is expected to conform to cultural expectations regarding masculinity. In mixed boarding schools where Keiyo initiated boys learn alongside girls, cultural expectations define their relationships. Bearing in mind that their cultural induction puts the man above the woman, these boys cannot compete effectively with girls since a good number of them feel superior to women and this poses a major challenge to their schooling process (Chang'ach, 2013). It can then be argued that culture imparts expressions of masculinities that impede some of the boys from attaining higher education (Bore, 2006). The close nexus between education and culture is also witnessed among the Ogiek boys. Leacock and Lee (1982) describe the Ogiek men after initiation as easily losing their temper, getting physical, fighting amongst themselves and beating their wives which is not considered distasteful. This has been observed as affecting their schooling adversely.

The boys in Turkana and Samburu go through different processes of becoming men. Finke's (2000-2003) work indicates that the Turkana do not practice circumcision; but simply go through the Atapan ceremony that transits them into adulthood by simply placing a blue ochre mud cup on their heads while the Samburu undergo the circumcision ritual, the Muratare e Layiokthat transits them into adulthood and warrants them a direct entry into warrior hood. The two communities express masculinities as demanded by their culture since they would be criticized if they do not. However, the main question relates to whether the differing initiation ceremonies between the Turkana and Samburu communities determine the kind of cultural masculinities that are expressed by the boys and their effects on school performance.

\subsection{The Effects of the Cultural Expressions of Masculinities on Educational Processes}

There are many unexamined beliefs such as those propagated by the Samburu and Turkana culture of initiation. These beliefs lead to cultural expressions of masculinities by boys of these communities and may affect educational processes. A lot of studies have been conducted on the techniques of knowledge transmission among the Turkana and Samburu but very little has been done to compare the effects of these cultural expressions of masculinities between the two communities; and how they influence education processes.

Globally, cultural expressions of masculinities have had both positive and negative impacts on the educational processes. Studies such as UNGEI (2006) highlight that socialization of boys within different cultures create different perceptions of masculinities in the men in the Asia-Pacific Countries. The study confines its arguments to the gender enculturation in schools but does not focus on the effects of the expressions of masculinities in the schooling processes. On another note, Stromquist (2007) explains that gender biased school environments and socialization encourages boys to be violent, tough or hyper-competitive in Australian schools. This study acknowledges the fact that the making of men creates different masculine expressions like control, toughness and competitiveness. Nonetheless, focus has only been shed on the school being a place where gender construction is manifested, as it provides a ground for a discussion and understanding of the different behaviours that are manifested but not in the classroom setting (Gill \& Starr, 2000).

In addition, UNICEF (2005) writes that after having gone through initiation, a great number of boys visualize education as not being 'masculine enough'. A good example is that of reading texts in class which they consider as a girls' activity. Further, UNICEF sees the school as gendered environment and calls for an inclusion of the boys in efforts to reconceptualize the negative gender stereotypes and attributions. Though this report indicates that the initiated boys in the class fail to participate in the educational process, many aspects that shape the educational processes have been left out. These include relations with the teachers and other students, participation in other learning activities like asking and answering questions amongst others. This study filled these gaps by focusing on the process of becoming men, the attributes that the boys acquire during and after initiation; paired with how they behave when confined to the classroom setting.

Regionally, the crisis of masculinity is vivid in the education process (McDowell, 2000). According to Longlands (2008) many boys are disengaged with the entire schooling process and a good number of them do not want to engage in the formal education programmes. The author gives an example of South Africa where many boys are involved in gang culture; hindering them from getting involved in schooling process. Their cultural attitudes are responsible for their 
limitation in the opportunities that they would otherwise accrue from educational processes. In the long run, high dropout rates are recorded and many others just go to school for the sake of it.

In Kenya, cultural expressions of masculinities have been viewed to be among the major drivers of boy's educational processes. Chege and Likoye (2015) add vital literature to this study by examining the perceptions that teachers and parents have on masculinity construction among school boys vis-à-vis schoolgirls in Kirinyaga and Nairobi counties. Particularly, they interrogate how school boys handle their being in school especially after having constructed masculinities during their transition to adulthood. We acknowledged the fact that the authors present the school setting as a gendered setting. Chege, Likoye, Nyambura and Guantai (2013) study the declining participation and performance of boys in Kenya in schools. The work supposes that the formed masculinities could be one of the variables affecting the education of the boys. Ogachi (2011) describes how culture and education have a symbiotic relationship. He further highlights that various cultural factor affect some aspects of education like the curriculum, the discipline of the student, the teacher relations and the school in general.

\section{Methodology}

The study from which the article is drawn utilized a comparative case study; conducted at Maralal Mixed Day Secondary School in Samburu Central constituency, Ikuruto Division between May 2017 and September 2019. The respondents of the study were 12 Turkana boys, 30 Samburu boys and 36 girls, giving a total of 78 student respondents; 3 education officials and 11 teachers (both male and female and inclusive of the principal and deputy principal). The whole school population was 250 students. It is from this target population that a sample of $30 \%$ was drawn. The researcher collected the primary data using observation checklists in the classroom setting. Questionnaires and interview guides were also employed. Additionally, secondary data was collected from the schools and communities' documents, records and other resource materials. Quantitative data was coded and analyzed using the IBM Statistical Package for Social Sciences (SPSS) version 23. Quantitative data analysis used statistical methods such as simple descriptive statistics, frequencies, percentages, bar graphs and pie charts. Qualitative data on the other hand was presented through verbatim and narratives; and inquiry conducted using content analysis methodology. The data was categorized based on its nature, such as verbal and behavioural data.

\section{Results and Analysis}

Part of what the larger study endeavoured to find out was the effects of cultural expressions of masculinities among the Turkana and Samburu boys on educational processes. The respondents were interrogated through the use of questionnaires on (1) how education has affected them and; (2) if culture affected the way they behaved in class. Selected teachers, female students and education officials were interviewed.

\subsection{Effects of Education on Turkana and Samburu}

How education has affected Turkana and Samburu boys was discussed under the following sub-themes, (a) Education being the pathway to their success (b) Education being used as a tool to transform youth in society, (c) how education would help them lead better lives than those of their parents; and (d) Whether or not education is a barrier that prevented them from practicing what their culture expects of them.

\subsubsection{Education as a Pathway To Success}

This section sought to understand whether education was a pathway to success. When respondents were asked whether education was a pathway to their success, they responded as depicted on Tables $1 \& 2$. The frequencies on the tables show the responses on education being the pathway to success for the Turkana respondents and Samburu respondents respectively. Fifty percent (50\%) of the Turkana respondents agreed to the statement to a great extent, $25 \%$ to some extent and $25 \%$ to a small extent. Their Samburu counterparts recorded $60 \%$ to a great extent, $26.7 \%$ to some extent and $13.3 \%$ to a small extent. On the same note, teachers and the education officials were interviewed on whether the students viewed education as a pathway to success. They indicated that for a long time they had been recording low performance from the boys, who otherwise have potential, but are constrained by their cultural demands on embracing education.

\begin{tabular}{|c|c|c|c|c|c|}
\hline \multicolumn{6}{|c|}{ Education is a Pathway to My Future Success } \\
\hline \multicolumn{2}{|c|}{} & Frequency & Percent & Valid Percent & Cumulative Percent \\
\hline Valid & Great extent & 6 & 50.0 & 50.0 & 50.0 \\
\hline & Some extent & 3 & 25.0 & 25.0 & 75.0 \\
\hline & Small extent & 3 & 25.0 & 25.0 & 100.0 \\
\hline & Total & 12 & 100.0 & 100.0 & \\
\hline
\end{tabular}

Table 1: Education being the Pathway to Success for Turkana Respondents

However, there were positive responses from them as they indicated that the boys have been showing some forms of good progress in education but after constant counselling. The head of the Guidance and Counselling department noted,

'... I have been working tirelessly with the boys to make sure that they change their perception towards education. We are hopeful that we will get there...' (O.1: Ms. Akavanga*, 21/10/2016). 


\begin{tabular}{|c|c|c|c|c|c|}
\hline \multicolumn{7}{|c|}{ Education is a Pathway to My Future Success } \\
\hline \multicolumn{2}{|c|}{} & Frequency & Percent & Valid Percent & Cumulative Percent \\
\hline Valid & Great extent & 18 & 60.0 & 60.0 & 60.0 \\
\hline & Some extent & 8 & 26.7 & 26.7 & 86.7 \\
\hline & Small extent & 4 & 13.3 & 13.3 & 100.0 \\
\hline & Total & 30 & 100.0 & 100.0 & \\
\hline
\end{tabular}

Table 2: Education Being the Pathway to Success for Samburu Respondents

The findings implied that in this time and era, some students do not value education as much as it would be expected, but there is hope for a better performance if they change their attitude towards education.

\subsubsection{Education as a Tool to Transform Youth in Society}

Secondly, the study sought to find out if the respondents felt that education could be used as a tool to transform the youths on the society. Of the Turkana respondents, $83.3 \%$ indicated that education would transform their lives to a great extent while $16.7 \%$ felt that it would only to some extent. On the other hand, $66.7 \%$ of the Samburu respondents indicated that education would transform their lives to a great extent; and $23.3 \%$ to some extent and $10 \%$ to a small extent. The findings revealed that the students seemed to be aware that education will transform their lives. More positively some students indicated that though they do not perform as per their expectation, school had transformed their lives in different ways. One of the female respondents interviewed said that;

'... I am hopeful of the future and that the education I have acquired has made me see life positively...' (O.1: Kristine*, $21 / 10 / 2016)$.

The specific reasons given by the male students from Samburu community were;

'...Many people got skills of doing famous things which help the society for example one can become a teacher and assist others to follow his way...' (0.1:Lentano*, 21/10/2016).

'...When one is educated in the society and pursue his or her course and get employed this supports the spirit of those who are in schools and strengthen their attitude so that they will become better than that person. 'Nowadays education is the key to live...'(0.1:Kanite*, 21/10/2016).

'If you are not educated you cannot transform yourself. It is a tool of life because without education you cannot prosper in life without education'(0.1:Lenaiyiarra *, 21/10/2016).

'Some years ago, in our village there lived a very poor man and he tried his best to get his son educated and when his son finished education, he got a job and lifted other youths' (0.1:Rurumban*, 21/10/2016).

On the other hand, the views by male students from Turkana community were;

'I believe that education can improve my living standards. Education change people, because a person who has got education is not tribal' (0.1:Ekomwa*, 21/10/2016).

'In order for you to be accepted in life you must go through education. You cannot do without it, so it is a must. If you manage to pass your examination well, you will get a job' (0.1:Chegem*, 21/10/2016).

These verbatim responses indicated that the Turkana and Samburu respondents believe that acquiring education can improve their lives in terms of handling issues in life and that they will approach life with a positive mind-set. They also believed that they would lead a better life with education through acquiring jobs. The respondents also felt that they would not transform their lives without education going with the idea that it unites them as a community regardless of their tribe. These findings are line with the study conducted by Karanu, Murenga and Osamba (2015) who opine that with the sensitization on the importance of schooling there are high chances that there will be minimal cases of school dropouts and high enrolment rates especially in the ASAL regions. The work also recommends the sensitization on the value of education among the pastoral communities like Samburu and Turkana which will help in raising the education status for the learners (Karanu, et al., 2015).

\subsubsection{Education as a Means to Leading a Better Life}

Thirdly, the study sought to find out if the respondents thought that education would help them lead a better life than that of their parents. The results are displayed on Tables $3 \& 4$.

\begin{tabular}{|l|l|l|l|l|l|}
\hline \multicolumn{5}{|c|}{ Education Will Help Me Lead a Better Life Than That of My Parents in the Village } \\
\hline & Great extent & 10 & Percent & Valid Percent & Cumulative Percent \\
\hline Valid & Some extent & 1 & 83.3 & 83.3 & 83.3 \\
\hline & Small extent & 1 & 8.3 & 8.3 & 91.7 \\
\hline & Total & 12 & 8.3 & 8.3 & 100.0 \\
\hline
\end{tabular}

Table 3: Turkana Respondents on Whether Education Will Help Me Lead a Better Life than That of My Parents in the Village

From the findings, $83.3 \%$ of the Turkana respondents indicate that education will help them to areat extent lead a better life than that of their parents in the village, $8.3 \%$ to some extent and 8.3 to a small extent. On the other hand, 73.3 $\%$ of the Samburu respondents indicated that education will help them lead a better life to a great extent and $20 \%$ to some extent and $6.7 \%$ to a small extent. 
The girls interviewed were hopeful despite their culture constraining them in advancing their education; the far they have gone is a step towards a better life than that of their parents. They said;

‘ Despite our culture preventing us from advancing our education, we have made major steps towards a better life than that of our parents' (0.1:Chegem\&Ewaso*, 21/10/2016).

However, differing sentiments are presented by the education officials who indicated that some boys still focus on herding and other activities like selling items in the market to get money than sit in class.

'Regardless of our efforts, some boys prefer herding and other activities like selling items in the market than sitting in class...' (0.1:Lesorogol\&Lesukat*, 21/10/2016).

These findings imply positive responses on the value of education. The Turkana and Samburu boys accepted that education would improve their lives. However, a percentage of boys believed that education would not impact their lives positively and sought to change their livelihoods by leaving school for herding and other activities which they perceived as better options.

\begin{tabular}{|c|c|c|c|c|c|}
\hline \multicolumn{6}{|c|}{ Education Will Help Me Lead a Better Life Than That of My Parents in the Village } \\
\hline \multicolumn{2}{|c|}{} & Frequency & Percent & Valid Percent & Cumulative Percent \\
\hline & $\begin{array}{c}\text { Great } \\
\text { extent }\end{array}$ & 22 & 73.3 & 73.3 & 73.3 \\
\hline $\begin{array}{c}\text { Some } \\
\text { extent }\end{array}$ & 6 & 20.0 & 20.0 & 100.0 \\
\hline $\begin{array}{c}\text { Small } \\
\text { extent }\end{array}$ & 2 & 6.7 & 6.7 & \\
\hline & Total & 30 & 100.0 & 100.0 & \\
\hline
\end{tabular}

Table 4: Samburu Respondents on Whether Education Will Help Me Lead a

Better Life than That of My Parents in the Village

\subsubsection{Education as a Barrier Preventing the Practising of Cultural Expectations}

Fourth, the respondents were questioned on whether education was a barrier that prevents them from practicing what their culture expected of them, as way of assessing how they perceive education. Ten (10) of the Turkana respondents $(83.3 \%)$ indicated that education was a barrier preventing them from acting as per their culture, especially taking directives from women, and even being defeated by girls in tests, yet they believe themselves to be superior. However, 1 respondent ( $8.3 \%$ ) gave no response while the other $(8.3 \%)$ believe that education was a barrier to some extent. On the same note, 14 Samburu respondents (46.7\%) said that education does not make them inferior even to female teachers, and that they are positive to the instructions they were given by them. However, $16.7 \%$ ( 5 respondents) said that education just intimidates them especially considering they were of higher age sets that command respect; instead of being commanded by 'inferior beings' like the female teachers. One of the respondents noted,

'School intimidates us especially we must follow the school rules and even take instructions from female teachers who are inferior to us. The school then prevents me from practicing what my culture expects of me ...' (0.1:Lesor*, 21/10/2016).

Many Samburu boys do not perceive school as a barrier even though during the course of socialization, they were forbidden to act like women, be around women or even associate themselves with female like activities. They were very aware and accepted the essence of respecting women. On the other hand, their Turkana counterparts perceived education as undermining to their status especially in the classroom setting. This is resultant to conforming to set rules, even the ones that have been set by their teachers, especially the deputy principal who was a woman at the time of the study.

\subsection{Effects of Culture on Student Classroom Behaviour}

The responses on the question of culture affecting the way they behaved in class shall be discussed under (a) Culture affects the way students viewed themselves in the classroom setting (b) If the respondents have other alternatives to education and (c) If culture affected the schooling process.

\subsubsection{Effects of Culture on How Students Viewed Themselves in Class}

The study sought to find out if culture affected the way students behaved in the classroom setting. The section highlights the following aspects of culture and their effects on student participation in class (a) community values associated with masculinity such as authority from male figures (b) adornment in traditional attire and (c) involvement in male-related activities like raiding after the initiation process. According to data collected from the male students $69.01 \%$ agreed with the statement that culture affects the way they view themselves in school, while $30.95 \%$ did not. Hence, based on the selected male students culture affects their perception of school and at times, plays no role in the way they perceive themselves being in school. One of reasons given by the male students from Samburu community was as follows;

'My culture has taught me to be aggressive and brave especially after circumcision. I struggle to get the best'.(0.1:Litiiyo*, 21/10/2016).

The student went on to explain that their culture expects them to be brave and aggressive after the initiation process. With the classroom, being a gendered institution, the Samburu had to show their prowess and strength through striving to achieve in Mathematics and Physics that were constantly regarded as tough subjects and were poorly performed in the school. He also said that he was proud of himself for improving in the subjects from the previous exams. 
Yet another respondent said that despite their cultural constraints, he will strive hard to achieve and pursue Engineering. He said that;

'... my culture affects the way I am in school by struggling to find out means that can assist me to succeed in education like working hard and being tough like my elders taught me. I am not defeated by others even in many tough subjects like Math and I vow to study Engineering in future'. (O.1:Lekaikum*, 21/10/2016).

However, he was keen to note that he will not forget his culture despite any eventuality.

'...many times, my old parents provide me with a lot of support so that I can raise them from where they are. They say education will make me better, but not to forget my culture...'

0.1:Lekaikum*, 21/10/2016).

Conversely, the male students from Turkana community said culture affects their being in school because the school has all forms of authority including the women teachers and their culture forbids them from being degraded by women, such as through being canned and punished by them. A respondent quoted;

'...they say that a man is not supposed to be in school and/or beaten by a female teacher. My villagers think that school makes a person backward and even leave his cultural values. (O.1:Moroto*, 21/10/2016).

The respondent complained that his village mates did not want to associate with him for having enrolled in school and even adorning school uniform besides the traditional Samburu adornment. He complained;

'...people of my age do not associate with me because they think I'm still under others' command, like female teachers who tell me to wear school uniform and remove my bangles, which is a cherished attire in my community, and put them on when I am out of school. Sometimes I even feel embarrassed going to school, because I know I will behave like a school boy not a man (0.1:Moroto*, 21/10/2016).

However, other Turkana respondents did not view their culture as affecting their being in school and were positive that their efforts in school will bear fruit. Rotino (not his real name) stated that;

'...I will tolerate being in school because one day I will be a better person even if people in my culture think I am getting lost. (0.1: Rotino*, 21/10/2016).

Nonetheless, he said that their being in school is short-lived as they break for midterm and schools close. During these breaks culture comes into play as he said when they get home, culture takes root again.

'...After closing school we interact with our culture and forget books. I forget the advice of the teachers so our culture affects my education while at home.' (O.1: Rotino*, 21/10/2016).

The girls interviewed said that they were performing reasonably well because they had the permission and good will from their parents. They strived to work extremely hard to perform and even beat the boys in exams. However, they also said their schooling faced with many challenges, the greatest was being undermined by their male counterparts who still view them as women in the village and not like fellow students in class. One female respondent (Akai, not her real name) said that their male Mathematics teacher is not confident that they can succeed in Mathematics. He continually mocked them to go and 'read stories' in the History and CRE lessons that matched their ability and intelligence since girls were preconceived to be good in feminine related subjects like the Arts.

'...Our Math teacher thinks that we can only do well in History and subjects like CRE and mocks us to go hear the narratives in those lessons, and leave Mathematics for the boys.' (0.1: Akai*, 21/10/2016).

The response from the female respondent is in line with Ngugi (2016) who explains how girl education is endangered in the pastoralist communities like the Turkana where the girls are sometimes forced to come to school with their siblings. At times, the elders in the community choose to have the girls married off so that they could get wealth from their bride price as opposed to taking them to school. At times they are perceived not to have the ability to fit in a school system as education is too tough for them. Such factors then put the girl education at stake, especially in the male dominated pastoral communities, where the men have naturally been given the right over women in masculinized and patriarchal societies.

On the other hand, Keti (2016) writes that girls are doing well in school and out of the best five candidates in Samburu who scored A- in the 2016 KCSE examinations; three of them were girls. The author says that this performance is in line with the fact that these girls have been given permission by their parents to study, despite a good number of them still not enrolling in school. From a feminist point of view, it is possible to understand why many girls still do not go to school, as they face barriers emanating from the patriarchal structures in the society that seek to ensure the men dominate the women who are confined in the private sphere of the home (Tong, 2011). The low enrolment of the girls in the secondary schools can also be understood based on the Connell's theory of masculinity, specifically the complicit masculinities as this form of masculinity involves subordination of women through the patriarchal divide (Connell, 2005). Hegemony is then gained effortlessly through culture, institutions and persuasion that allow for domination of women.

The verbatim from the male respondents are also in line with the views of Egel (2009) that the classroom cannot be alienated from a discussion of culture. The author further explains that a good number of teachers are not culturally responsive; hence, hinder interconnectedness between them and their students. Undoubtedly, these findings show new trends taking place in the education sector among the marginalized communities. A number of the respondents indicated that their culture affected them both in a positive and negative way as far as education was concerned. Some believed that circumcision/ initiation led to them acquiring attributes such as bravery, aggressiveness and diligence to deal with many issues they face in the classroom setting like dealing with 'tough' subjects like Mathematics and Sciences. On the other hand, others more so, from the Turkana community felt that their culture was being undermined when they went to school, and are even forced to be in school uniform. Worse still, they felt undermined being punished by female teachers and even being subjected to school rules. The different responses from the two communities give a clear indication of the concept of culture and its effects on education. 


\subsection{Do You Have Other Alternatives to Education?}

The study sought to find out if the respondents had other alternatives to education considering that they were so immersed in their culture. The researcher used questionnaires to collect the required information.

\begin{tabular}{|c|c|c|c|}
\hline \multicolumn{4}{|c|}{ Do You Have Other Alternatives to Education? } \\
\hline & Yes & No & Frequency \\
\hline Turkana & 9 & 3 & 12 \\
\hline Samburu & 12 & 18 & 30 \\
\hline Percent & $50 \%$ & $50 \%$ & \\
\hline
\end{tabular}

Table 5: Other Alternatives to Education for Turkana and Samburu Respondents

The findings indicated that $50 \%$ of the male students alluded to having other preferred alternatives to education as opposed to being in school for years. There was an equal proportion of boys disagreeing with the statement. Some of the alternatives given by the male students from Samburu community were herding their livestock, cultivating crops and doing business in the market. In majority of the responses, 'cultivating crops, herding and doing business', '...raiding our neighbors for cattle and herding in the bushes'were some of the alternatives to education as illustrates in the verbatim below;

'...We have the alternative of cultivating crops, trading, doing business, and herding our cattle' (0.1: Lengees\& Lekaikum*, 21/10/2016).

However, others despite having the alternatives said that education matters a great deal to their lives. They stated that,

'...After our high school level we would like to pursue other courses such Certified Public Accounts (CPA) so that we get jobs and help our families and ourselves' (O.1: Lesurmat\&Lkicheunye*, 21/10/2016).

Another said,

'...Actually, they say that education has no end so I am focusing ahead to achieve my life targets...'(O.1: Ltalipen*, 21/10/2016).

Samburu participants' responses could be explained using Letiwa's (2017) arguments that relate to the great strides that have been experienced in education among the Samburu. This is as a result of the creation of more schools that has led to the Samburu embracing education; especially by the locals who even take part in the building of schools. The boy respondents who alluded to have other alternatives to school are clearly affected by cultural constraints; with their parents preferring them to be herders and be involved in cattle rustling rather than attending school. For these parents, education is a less important option in their children's future.

Seventy-five percent of the Turkana respondents (9 out of 12) argued that they had many alternatives to education highlighting herding as a key example of the alternatives.The male students from Turkana community gave the following alternatives;

'...My parent does not support my education so I will finish and go to Baragoi to herd'. '... will go to the village and herd my grandfather's cattle and be rich from my cattle'

(0.1: Lterewa\&Nabaru*, 21/10/2016).

The responses from the Turkana students relate to those of Galván (2014) who explains that cultural traditions are still alive in such pastoral communities. Education to them, therefore, seems unresponsive to pastoralist demands. UNESCO (2010) writes that pastoralist livelihoods are mobile and are geared towards seasonal calendars that involve grazing and availability of water. This makes the respondents then visualize the school curricular as having very little relevance to their lives as pastoralists. However, there is hope for a brighter day if the traditional practices like cattle rustling are discouraged among pastoral communities.

\subsubsection{How Culture Affects the Schooling Process}

As a way of assessing the effects of cultural processes on participation in educational processes, the study sought to assess if culture affected schooling. The findings can be seen on Table 6.

\begin{tabular}{|c|c|c|c|}
\hline \multicolumn{4}{|c|}{ Does Culture Affect Your Schooling? } \\
\hline & Yes & No & Frequency \\
\hline Turkana & 11 & 1 & 12 \\
\hline Samburu & 22 & 8 & 30 \\
\hline Percent & $78.50 \%$ & $21.40 \%$ & \\
\hline
\end{tabular}

Table 6: Effects of Culture on the Schooling Process

The study found out that the respondents had the hope of ascending to higher levels of education after high school. Upon interviewing the girls, the findings revealed that they hoped to ascend to the university level (78\%) though some $(12 \%)$ had no idea on the effort required to excel to such heights. The study also found out that $78.5 \%$ percent of the male students intended to ascend to higher educational opportunities after high school. This can be interpreted to mean that education is seemingly important to them to a great extent, despite the low performance recorded in their examination results. The qualitative responses from the Samburu male students in regards to their perception on education were; 
'Education is as an important thing in my life as it can change me. Education is the key of life' (O.1: Lemoosa*, 21/10/2016).

'Culture affects education in our community for instance, after one has been circumcised a big percentage of boys drop out of school because school restricts people from doing other things like grazing because I have to be in school every day'(0.1: Letuk *, 21/10/2016).

The male students from Turkana community had similar responses as follows;

'Education is a basic need for all people and is the key of life' (0.1: Pkos*, 21/10/2016).

'Education now is the key to success because nowadays there is no other way to become better but only through education' (0.1: Lotiolo, *, 21/10/2016).

'Education has become one of the most important things and for you to succeed in life you must be literate' (0.1: Rotino*, 21/10/2016).

'Education is an important thing that would smoothen my life in future' (0.1: Lomunokol*, 21/10/2016).

Similar sentiments were echoed by one of the teachers who said,

'...It is somehow tricky to have the full attention of the boys in class. Some are very bossy and others are completely disinterested. It is devastating how, even the form fours, do not value education as much...'(0.1: Mr. Tuk*, 21/10/2016).

The male principal of the school also observed,

'...though a good number are conversant with the benefits of education, a lot needs to be done to eliminate the aspect of culture from their school life. Had it been a boarding school, it would have been better since they would be detached from their villages and focus on school work...' (0.1: Mr. Bok*, 21/10/2016).

The deputy principal who is a female stated,

'The boys are trying, but the value of education has not hit a good number of them. They could have other alternatives like herding that limits their perception on the value of education'.(O.1: Mrs. Lesa*, 21/10/2016).

Similarly, one of the teachers confessed,

'The boys behave well in class despite the challenges they face from home, being a day school. Though many have confessed having issues with staying in school due to wrong perceptions from various quarters, they are at pains on what to decide for their future. A good number are still lost in their cultural ideals'.(0.1: Mrs. Telai*, 21/10/2016).

An education official noted;

'In their struggle to conform to school rules and regulations the boys are more likely to go for suspensions or expulsions from school, therefore, the dropout rates are higher for them than for girls'.(0.1: Mrs. Lelei*, 21/10/2016).

The key informants were, therefore, of the view that though their performance was quite low, there is hope for better days as the boys are striving to conform with the school rules as opposed to the past when the older boys were rebellious to teachers especially the female teachers. Indeed, the teachers added that the boys struggle and show willingness to learn but at times, they respond aggressively to the school processes and some seem to struggle to conform to rules set in class. The male students accepted that being in school is profitable. However, it was noted that more needs to be done on the general performance of the students. This is due to the perception students still hold of there being other alternative to schooling such as herding; hence, placing less emphasis on the value of education.

\section{Conclusions}

The initiation of Turkana and Samburu boys led to cultural masculinity values such as authority of male over females, adornment in traditional attire and involvement in male-related activities like raiding for cattle among others. The expected ensuing behaviour would be the show of bravery, aggressiveness and diligence in dealing with many issues facing them in the classroom setting. These cultural expressions of masculinities among the Turkana and Samburu boys have positive and negative effects on the education of the boys. Both Turkana and Samburu respondents believed that acquiring education could improve the ways in which they handled issues in life and to approach life with a positive mindset. They also believed that they would lead a better life with education through acquiring jobs. The respondents also felt that education unites them as a community regardless of their tribe. These findings imply positive responses on the value of education. The Turkana and Samburu boys accepted that education would improve their lives. However, a percentage of boys believed that education would not impact their lives positively and sought to change their livelihoods by leaving school for other activities which they perceived as better options such as herding. Many Samburu boys do not perceive school as a barrier even though during the course of socialization, they were forbidden to act like women, be around women or even associate themselves with female like activities. On the other hand, their Turkana counterparts perceived education as undermining to their status especially in the classroom setting with a female teacher.This makes the respondents then visualize the school curricular as having very little relevance to their lives as pastoralists.

\section{References}

i. Abbott, D. (2013). Britain's crisis of masculinity. Retrieved from http://www.demos.co.uk/files/DianeAbbottspeech16May2013.pdf

ii. Bore, K. M. (2006). The Kalenjin of Kenya, cultural diversity. Eldoret: Unlimited Literature Foundation.

iii. Chang'ach, J. K. (2013). Influence of Keiyo traditional circumcision on aspirations for higher education among boys in secondary schools, Keiyo South District,Elgeyo-Marakwet County, Kenya. American International Journal of Contemporary Research, 3 (4), 41-53. 
iv. Chege, N. F. \&Likoye, F. (2015). Perceptions of parents and teachers on constructions of masculinities among primary schoolboys Kirinyaga and Nairobi Counties, Kenya.Unpublished. https://doi.org/10.13140/rg.2.1.1367.9524

v. Chege, N. F., Likoye, F., Nyambura, S. \&Guantai, H. K. (2013). Declining boys' participation and performance in Kenyan Schools: Are girls' education projects influencing new forms of masculinities? CICE 5 Africa-Asia University Dialogue for Educational Development: Final Report of the Phase II Research Results:(1) Gender and Equity, 1-17.

vi. Christine, S. \& Becky, F. (2003). Boys and girls in the primary classroom. London: McGraw-Hill Education (UK).

vii. Coffey, A. \& James, D. (2016). Masculinity and education. London: Routledge.

viii. Connell, R. W. \&Messerschmidt, J.W. (2005). Hegemonic masculinity: Rethinking the concept. Gender and Society 19(6), 829-59.

ix. Connell, R.W. (2010). Education, change and society. Oxford: Oxford University Press.

x. DiPrete, T. A., \&Buchmann, C. (2013). The rise of women: The growing gender gap in education and what it means for American Schools. Russell: Sage Foundation.

xi. Egel, İ. P. (2009). Learner autonomy in the language classroom: from teacher dependency to learner independency. Procedia Social and Behavioral Sciences, 1, 2023-2026.

xii. Epstein, D., Elwood, J., Hey, V. \& Maw, J. (eds) (1998). Failing boys? Buckingham: Open University Press.

xiii. Finke, J. (2000-2003). Turkana - Society. Retrieved from http://www.bluegecko.org/kenya/tribes/turkana/society.htm

xiv. Francis, B. (2000). Boys, girls and achievement. London: Routledge/Falmer

xv. Galván, J. A. (2014). They do what?: A cultural Encyclopedia of extraordinary and exotic customs from around the World. NY: ABC-CLIO.

xvi. Gill, J. \& Starr, K. (2000). Sauce for the goose? Deconstructing the boys-in-education push. Discourse: Studies in the cultural politics of education, 21(3), 323-333. doi:

$10.1080 / 713661161$

xvii. Hargreaves, M., Homer, M., \&Swinnerton, B. (2008). A comparison of performance and attitudes in mathematics amongst the 'gifted'. Are boys better at mathematics or do they just think they are? Assessment in Education: Principles, Policy \& Practice, 15 (1), 19-38.

xviii. Heyder, A. \&Kessels, U. (2013). Is school feminine? Implicit gender stereotyping of school as a predictor of academic achievement. Sex Roles, 69(11-12), 605-17.

xix. Jha, J. \& Kelleher, F. (2006). Boys' underachievement in education. an exploration in selected commonwealth countries. London: Commonwealth Secretariat and Commonwealth of Learning.

xx. Karanu, M., Murenga, H. \&Osamba, J. (2015). Socio-cultural and economic factors affecting primary school enrolment in Baragoi division of Samburu County, Kenya. Asian Journal of Management Sciences \& Education, 4(2), 1-13.

xxi. Keti, J. (2016). Insecurity in Samburu blamed for drop in KCSE exam results. Retrieved from http://www.nation.co.ke/counties/Insecurity-blamed-for-poor-exam-results-Samburu/1107872-3108982sv6yvqz/index.html.

xxii. Kitetu, W. C. (2008). Gender, Science and Technology: Perspectives from Africa: Perspectives from Africa. NJ: African Books Collective.

xxiii. Krätli S. (2001). Education provision to nomadic pastoralists, IDS Working Paper 126, Brighton: Institute of Development Studies.

xxiv. Leacock, E. \& Lee, R. (1982). Politics and history in band societies. NY: CUP Archive.

xxv. Leaper, C. Farkas, T. \& Brown, S. (2012). Adolescent Girls' Experiences and Gender-Related Beliefs in Relation to Their Motivation in Math/Science and English. Journal of Youth and Adolescence, 41(3),268-82.

xxvi. Leaper, C. Farkas, T. \& Brown, S. (2012). Adolescent Girls' Experiences and Gender-Related Beliefs in Relation to Their Motivation in Math/Science and English. Journal of Youth and Adolescence, 41(3),268-82.

xxvii. Letiwa, P. (2017). Samburuherdsboy who rose to be lawyer, now county Speaker. Retrieved from https://nation.africa/kenya/counties/samburu/samburu-herdsboy-who-rose-to-be-lawyer-now-countyspeaker-481784?view=htmlamp

xxviii. Longlands, H. (2008). Boys in schools: Masculinities, education and gender equality. beyond access. Gender, Education and Development, 21, 1-12.

xxix. Martino, W. (2008). Boys' underachievement: Which boys are we talking about? Research Monograph, 12.

xxx. McDowell, L. (2000). The trouble with men? Young people, gender transformations and the crisis of masculinity. International Journal of Urban and Regional Research, 24(1), 201-209.

xxxi. Ngugi, M. (2016). Challenges facing mobile schools among nomadic pastoralists: A case study of Turkana County, Kenya. J American Journal of Educational Research, 4(1), 22-32.

xxxii. Richardson, H. (2011). African-Caribbean boys 'would rather hustle than learn'. BBC News, $21^{\text {st }}$ October 2011.

xxxiii. Ruto, J. et al (2009). Educational marginalisation in Northern Kenya. Background paper prepared for the education for all global monitoring report 2010.Retrieved from http://unesdoc.unesco.org/images/0018/001866/186617e.pdf

xxxiv. Stromquist, N.P. (2007). The gender socialization process in schools: A cross-national comparison. Background paper prepared for the Education for All Global Monitoring Report 2008 Education for All by 2015: will we make it? Retrieved from http://unesdoc.unesco.org/images/0015/001555/155587e.pdf 
xxxv. Tong, R. (2011). Feminist Thought. Colarado: Westview Press.

xxxvi. UNGEI (United Nations Girls Education Initiative) (2006). Why are boys under-performing in education? Gender analysis of four Asia-Pacific Countries. UNESCO.

xxxvii. UNICEF (2005). Masculinities: male roles and male involvement in the promotion of gender equality a resource packet. Retrieved from http://www.unicef.org/emergencies/files/male_roles.pdf 